University of Thi-Qar Journal Vol.10 No.2 June 2015

Web Site: https://jutq.utq.edu.iq/index.php/main Email: journal@jutq.utq.edu.iq

\title{
Dynamic analysis of elevated tanks having various supporting frame configurations
}

https://doi.org/10.32792/utq/utj/vol10/2/8

Mawahib A. Gate'a \& Dr. Abdulamir Atalla

Department of civil engineering, college of engineering, university of Basrah

\begin{abstract}
Liquid storage tanks and especially the elevated tanks are structures of high importance which are considered as main lifeline elements in modern life. As earthquakes are the most powerful and dangerous loads that storage tanks may suffer, the vibrated tank with or without a contained liquid is so critical case so that researchers and designers must give high interest while studying this type of structures.

In this work a free vibration analysis had been carried out for an empty elevated concrete cylindrical liquid storage tank supported on a frame consisted of four stories. Four values of height of the frame are explored; 12, 16, 20 and $24 \mathrm{~m}$ and four values of column angle of inclination; $0^{\circ}, 2.38^{\circ}$, $4.76^{\circ}, 7.125^{\circ}$ measured from the vertical are examined. The tanks are modeled by the finite element method and the analysis is conducted using ANSYS 11. The natural frequency is found to decrease with increasing in frame height and angle of frame inclination due to stiffness decrement of the supporting frame.

A forced vibration analysis is also done on a selected case of elevated tank under three filling percentages: $0 \%, 50 \%$ and $100 \%$.The seismically excited tank has a height of $15.9 \mathrm{~m}$ and is subjected to Kocaeli earthquake in Turkey, 1999. The dynamic response including the maximum stresses and displacements is determined and discussed.
\end{abstract}

Keywords: Dynamic analysis, seismic loads, elevated storage tank, mode shapes.

\section{Introduction}

Water tanks are very important structures which supplying water for drinking, firefighting and other industrial facilities of recent life [1]. The failure of these structures may cause some hazards for the health of city due to the shortage of water or difficulty in putting out fire during critical conditions [2]. In the past earthquakes, it has been identified that the collapse of reinforced concrete elevated tanks under lateral earthquake loads have been extremely susceptible [3], therefore the dynamic 


\section{University of Thi-Qar Journal Vol.10 No.2 June 2015}

Web Site: https://jutq.utq.edu.iq/index.php/main Email: journal@jutq.utq.edu.iq

response of liquid storage tanks subjected to earthquakes was a subject of numerous studies in the past 30 years [4].

Omidinasab and Shakib 2008 [2] evaluated the demand of a reinforced concrete elevated water tank to an ensemble of earthquake records by using linear and nonlinear analysis. They concluded that structure responses for each record depend upon the structure's dynamic features, the frequency content and the earthquake characteristics. Lower stages were found to be more vulnerable than upper stages. Hirde et. al. 2011[5] presented a study of seismic performance of an elevated water tanks for various seismic zones of India with various heights and capacity of elevated water tanks and for different soil conditions; They observed that, earthquake forces decreased with increase in staging height because as staging height increases the structure became more flexible. Therefore time period increased due to which structural response factor decreases from lower to higher staging height. Patel et. al. 2012 [4] considered a reinforced elevated water tank supported by fixed base frame type staging system with different degrees of tapering. They assessed the sloshing response under four earthquake records for three cases; full, half full and empty. The critical response of elevated tanks may occur in full condition and also under half condition. The critical response depends on the earthquake characteristics and particularly frequency content of earthquake records.

\section{Description of the Elevated Tank}

A reinforced concrete elevated tank with a container capacity of $50 \mathrm{~m}^{3}$ is considered in the analysis as used in a previous work [5] (Fig.1). The elevated tank is supported by a hinged base boundary condition frame structure consisting of four columns with circular cross section of diameter equal to $450 \mathrm{~mm}$ which are connected laterally by rectangular horizontal beams $(300 * 450) \mathrm{mm}^{2}$ at heights of 3, 6, 9 and $12 \mathrm{~m}$ above ground. The vessel is cylindrical with base and cover rigidly connected with the tanks' walls. The container has a radius of $4.65 \mathrm{~m}$ and a height of $3.3 \mathrm{~m}$. Walls and floor plate have the same thickness of $200 \mathrm{~mm}$ while the roof thickness is $120 \mathrm{~mm}$. The ring beam under the tank is of rectangular cross section with $(250 * 600) \mathrm{mm}^{2}$ cross sectional dimensions. Mass density of the tank material is $2500 \mathrm{~kg} / \mathrm{m}^{3}$ and for water $1000 \mathrm{~kg} / \mathrm{m}^{3}$ respectively, Modulus of elasticity and Poisson ratio for concrete are (23.5 Gpa and 0.15$)$ respectively.

\section{Modeling}

The finite element software (ANSYS11) is used to model the cylindrical concrete elevated tank system. Columns and beams in the supporting frame are modeled with an elastic beam (BEAM4) element with six degrees-of-freedom per node and the container walls, roof, floor and the ring are modeled with quadrilateral shell (SHELL63) element with four nodes and six degrees-of-freedom per node. The fluid elements are defined by a point element (MASS21) having three degrees of freedom; 


\section{University of Thi-Qar Journal Vol.10 No.2 June 2015}

Web Site: https://jutq.utq.edu.iq/index.php/main Email: journal@jutq.utq.edu.iq

the translations in the nodal $\mathrm{x}, \mathrm{y}$, and $\mathrm{z}$ directions, using added mass method. The tank and the finite element model is shown in Figure (1).

\section{Governing Equation of motion}

The simplest method used to handle the fluid-structure interaction problems is the added mass approach. In the added mass approach, the fluid mass obtained by different ways is added to the mass of the structure at the fluid-structure interface. For a system subjected to an earthquake ground motion, the general equation of motion can be written as:

$$
\mathrm{MU}+\mathrm{CU}+\mathrm{kU}=-\mathrm{MU}_{\mathrm{g}}
$$

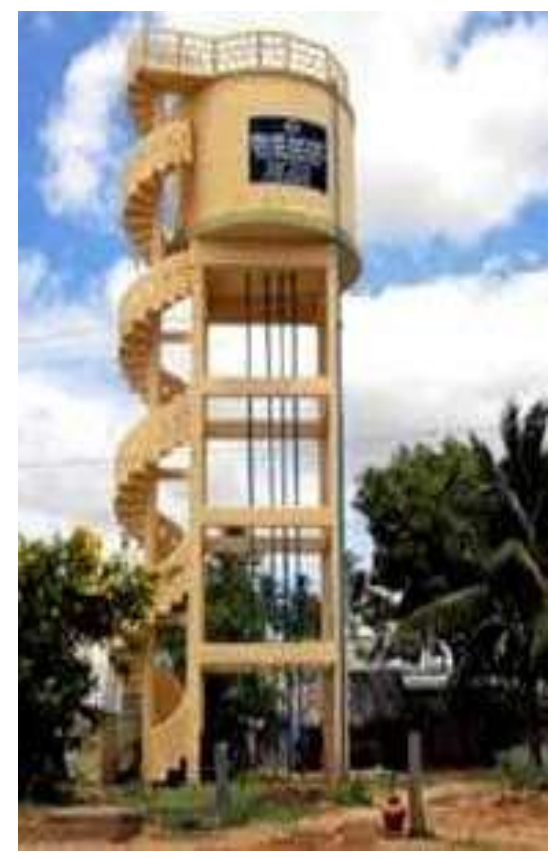

(a)



(b)

Figure (1) elevated tank considered in this study. a) Physical model, b) FE model

where $\mathrm{M}$ is the mass matrix, $\mathrm{C}$ the damping matrix, $\mathrm{K}$ the stiffness matrix, $\ddot{U}_{\mathrm{g}}$ the ground acceleration, $U$ the relative displacement and the over dots denote the derivatives of $U$ with respect to time. If the added mass approach is used, the previous equation changes in the following form:

$$
\mathrm{M}^{*} \ddot{\mathrm{U}}+\mathrm{C} \dot{U}+\mathrm{kU}=-\mathrm{M}^{*} \ddot{\mathrm{U}}_{\mathrm{g}}
$$

Where $M^{*}$ is the total mass matrix consisting of the structural mass matrix $M$ and added mass matrix (Ma). In this approach, it is assumed that the added mass (Ma) which will be added to nodes on the wall, are determined from the mass of the impulsive liquid.

\section{Results and discussion}

\subsection{Free vibration analysis}




\section{University of Thi-Qar Journal Vol.10 No.2 June 2015}

Web Site: https://jutq.utq.edu.iq/index.php/main Email: journal@jutq.utq.edu.iq

To define the dynamic characteristics of the elevated water tank and determine the seismic behavior of the system, first, free vibration analysis was carried out. Natural frequencies and the corresponding mode shapes were obtained for the general case of the empty tank (vertical frame with $12 \mathrm{~m}$ height). The values of natural frequencies for the first five modes together with the mode shapes and description are expressed in Table (1)

Table (1) Natural frequencies and mode shapes for the first five modes

\begin{tabular}{|c|c|c|c|c|}
\hline $\begin{array}{l}\text { Mode } \\
\text { No. }\end{array}$ & Mode & & Mode description & $\begin{array}{l}\text { Natural } \\
\text { frequency } \\
(\mathrm{Hz})\end{array}$ \\
\hline 1 &  & AN & $\begin{array}{l}1^{\text {st }} \text { Beam mode } \\
\text { (cantilever } 1)\end{array}$ & 0.631 \\
\hline 2 & 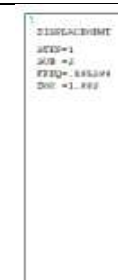 & 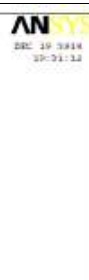 & $\begin{array}{l}1^{\text {st }} \text { Twisting mode } \\
\text { (rotation } 1 \text { ) }\end{array}$ & 0.805 \\
\hline 3 &  & AN & $\begin{array}{l}2^{\text {nd }} \text { beam mode } \\
\text { (cantilever2) }\end{array}$ & 2.316 \\
\hline 4 &  & $\mathbf{A N}$ & $\begin{array}{l}2^{\text {nd }} \text { Twisting mode } \\
\text { (rotation } 2 \text { ) }\end{array}$ & 3.067 \\
\hline
\end{tabular}


Web Site: https://jutq.utq.edu.iq/index.php/main Email: journal@jutq.utq.edu.iq



\subsection{Effect of Frame Inclination}

In order to study the effect of inclination of the supporting frame on the natural frequency of the whole system, three angles: $2.38^{\circ}, 4.76^{\circ}$ and $7.125^{\circ}$, have been studied, measured between the inclined frame and the original position of the column. The distance between columns at the base becomes larger while it still constant in the top of frame. Values of $(\tan \theta)$ together with the obtained corresponding natural frequencies are listed in Table (2) and Figure (2).

Table (2) Natural frequency under various angles of inclination

\begin{tabular}{|c|c|c|c|c|}
\hline \multirow{3}{*}{ Mode No. } & \multicolumn{4}{|l|}{$\operatorname{Tan} \theta$} \\
\hline & 0 & 0.04 & 0.083 & 0.125 \\
\hline & \multicolumn{4}{|c|}{ Natural frequency $(\mathrm{Hz})$} \\
\hline 1 & 0.631 & 0.582 & 0.606 & 0.617 \\
\hline 2 & 0.805 & 0.787 & 0.809 & 0.814 \\
\hline 3 & 2.316 & 2.034 & 2.027 & 1.970 \\
\hline 4 & 3.067 & 2.742 & 2.646 & 2.560 \\
\hline 5 & 4.905 & 4.473 & 4.305 & 4.138 \\
\hline
\end{tabular}

It is found that the general trend of the natural frequency is decreased as the angle of inclination increase with different rates. This can be justified by the reduction of the stiffness of the horizontal supporting beams as the distances between the columns are increased. An exception of this trend is noted in some modes.

\subsection{Effect of frame height}

In order to determine how is the supporting frame height affects the results of the free vibration analysis; three heights $(16 \mathrm{~m}, 20 \mathrm{~m}$ and $24 \mathrm{~m})$ had been studied in addition to the original case $(12 \mathrm{~m})$ and the effects had been studied for empty case. The results are shown in Table (3) and Figure (3). 


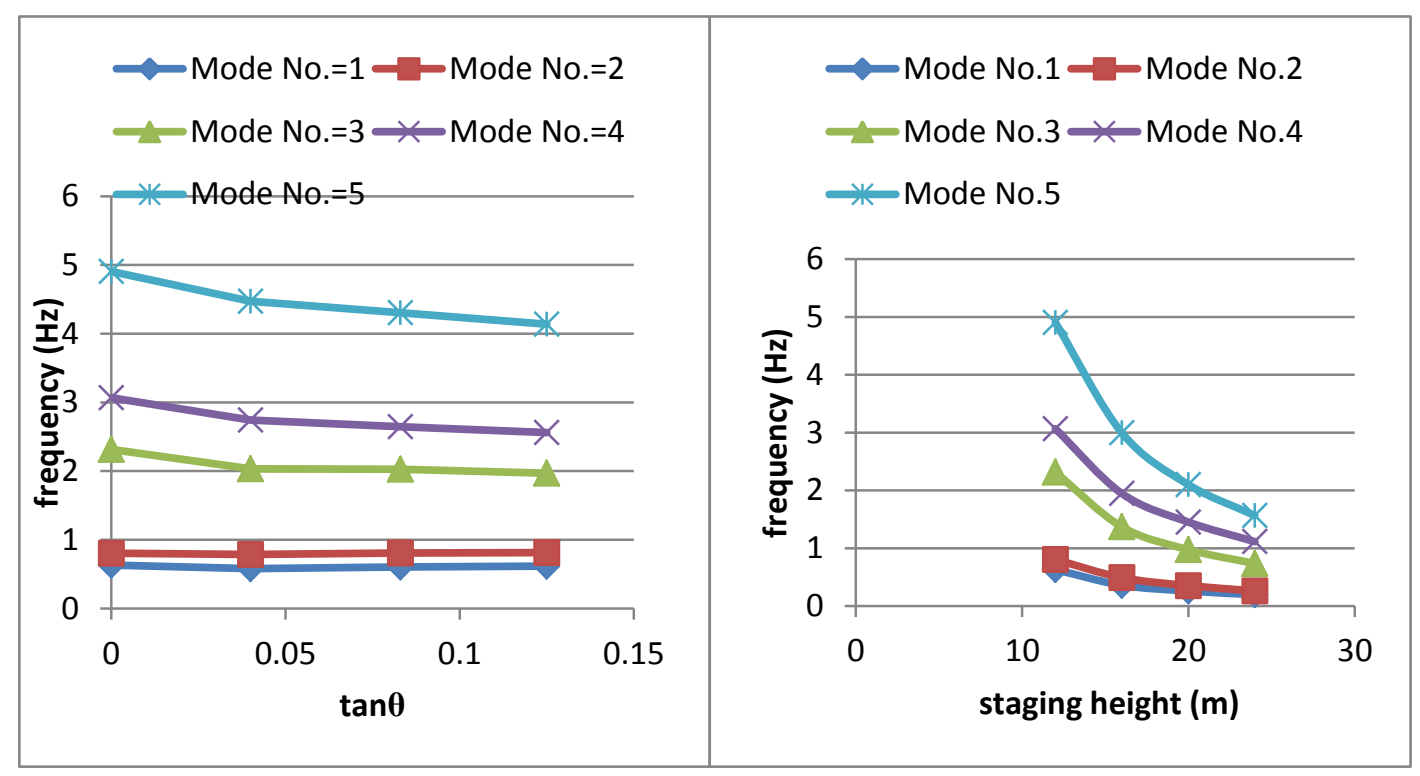

Figure (2) Effect of inclination angle on Figure (3)Effect of frame height on the the natural frequency natural frequency

Table (3) Natural frequency for different frame heights $(\beta=0)$

\begin{tabular}{|l|l|l|l|l|}
\hline \multirow{2}{*}{ Mode No. } & \multicolumn{4}{|l|}{ Natural frequency $(\mathrm{Hz})$} \\
\cline { 2 - 5 } & $\mathrm{H}=12 \mathrm{~m}$ & $\mathrm{H}=16 \mathrm{~m}$ & $\mathrm{H}=20 \mathrm{~m}$ & $\mathrm{H}=24 \mathrm{~m}$ \\
\hline 1 & 0.631 & 0.360 & 0.260 & 0.198 \\
\hline 2 & 0.805 & 0.491 & 0.353 & 0.263 \\
\hline 3 & 2.316 & 1.370 & 0.976 & 0.735 \\
\hline 4 & 3.067 & 1.947 & 1.452 & 1.114 \\
\hline 5 & 4.905 & 2.997 & 2.100 & 1.565 \\
\hline
\end{tabular}

The frequency, as shown in table(3) decreases when frame get longer for all modes ,that is because the additional length give additional mass and flexibility to the whole structure which result frequency decrease. Also the high length of columns decreases the stiffness according to the formula:

$$
k=\frac{E I}{L^{3}}
$$

Where,

E: Young modulus (Gpa). 


\section{University of Thi-Qar Journal Vol.10 No.2 June 2015}

Web Site: https://jutq.utq.edu.iq/index.php/main Email: journal@jutq.utq.edu.iq

I: Moment of inertia $\left(\mathrm{m}^{4}\right)$, and

L: Length of member.

These changes lessen frequency according to the formula:

$$
f=\frac{1}{2 \pi} \sqrt{\frac{k}{m}}
$$

Where,

$f$ : The natural frequency of the system $(\mathrm{Hz})$.

$k:$ is the stiffness.

$m$ : structural mass $(\mathrm{kg})$.

\subsection{Earthquake Ground motion}

Three cases including filled, half filled, and empty container are considered to assess the dynamic response of the elevated tank. Response spectrum analysis has been done to conduct this work. The tank is subjected to kocaeli earthquake, Turkey, 1999 with magnitude $\left(M_{w}=7.4\right)$ on Richter scale which has strong pulses nearly for 10 seconds.

The frequency content of the motions can also be compared; in acceleration response spectra Kocaeli Earthquake has its peak values in 0.2-0.3 seconds [7].

The horizontal components of Kocaeli earthquake acceleration are presented in Figure (4).

\subsubsection{Shear force}

It is clear from figure (5) that the values are approximately equal for all cases of filling in the nodes selected with low difference among them. Also, shear force values varies from positive at one level to negative at the next level, till to the end of frame height. At the end of frame and along the height of tank, shear values are almost small and convergent.

\subsubsection{Bending moment}

The bending moment had begun with a very small negative value in the frame supporting point and then it reflected between negative and positive values for the three cases of filling. It arrives it's maximum values at the ends of every story height. The values of the three cases are approximately the same with in the frame limits, a remarkable difference is happening in the beginning of tank height in case of full container due to the large mass added to the tank while, for the other cases the base moment values still near zero until the end of tank height. Figure (6) explains these variations of bending moment with the tank height. The value of the overturning moment about the $\mathrm{x}$-axis which is 


\section{University of Thi-Qar Journal Vol.10 No.2 June 2015 \\ Web Site: https://jutq.utq.edu.iq/index.php/main Email: journal@jutq.utq.edu.iq}

obtained from the element force of the column multiplied by the distance between columns is equal to 2.599, 2.606 and $2.612 \mathrm{kN} . \mathrm{m}$ for empty, half and full filling cases, respectively.

\subsubsection{Lateral displacement}

The values of displacement in the direction of earthquake (x-axis) have their peaks near the mid height of the supporting structure for the three filling cases in different rates due to the column bending, buckling and torsion occur in the frame as shown in figure (7). This makes the mid height location is the most critical among other points of structure. The lateral displacement in this location is found to be maximum for the case of half full tank and equal to $(0.9983 \mathrm{~m})$, while the minimum value of displacement occurs in the empty case and it is equal to $(0.112 \mathrm{~m})$. The displacements, as noticed, are so large that the elevated tank can lose stability even though the internal forces are small.

At the points above the mid height the displacement begins to decrease and then changes it's direction to the opposite one at the top of frame. Along the height of the tank wall the displacement is comparatively small and convergent, maximum displacement are noticed in case of full tank having a value of $(-0.26387 \mathrm{~m})$.

The relation between the filling ratio and the maximum displacement is shown in figure (8). The figure shows that maximum displacement occurs in case of half full container. This can be justified due to the coincidence between the frequency content of the earthquake and the natural frequencies of the tank when it is half filled. Figures (11), (12) and (13) show the contour plots for the displacement in case of full, half and empty vessel.

\subsubsection{Shear stress}

The critical points of the tank structure which suffer from maximum stresses are the points in the region around the points of connection with the supporting frame as shown in figure (9). These points are critical due to the large mass supported by four columns and the impulsive action in cases of water presence inside the container. Figure (10) explains the variation in the values of stress in the container only, including the bottom ring with the height along a vertical line located opposite to the direction of earthquake; the stress varies from maximum negative value in the bottom of ring to a specific positive value in the top of ring $(0.6 \mathrm{~m})$, then the curve returns to a low negative value in a height of $(1.3 \mathrm{~m})$ and remain constant in the rest heights. Stress is found to be extremely higher in empty case. Figure (14) is showing the contour plot of the stress on the tank base. The stress concentrations near the connection points can obviously be noted. 


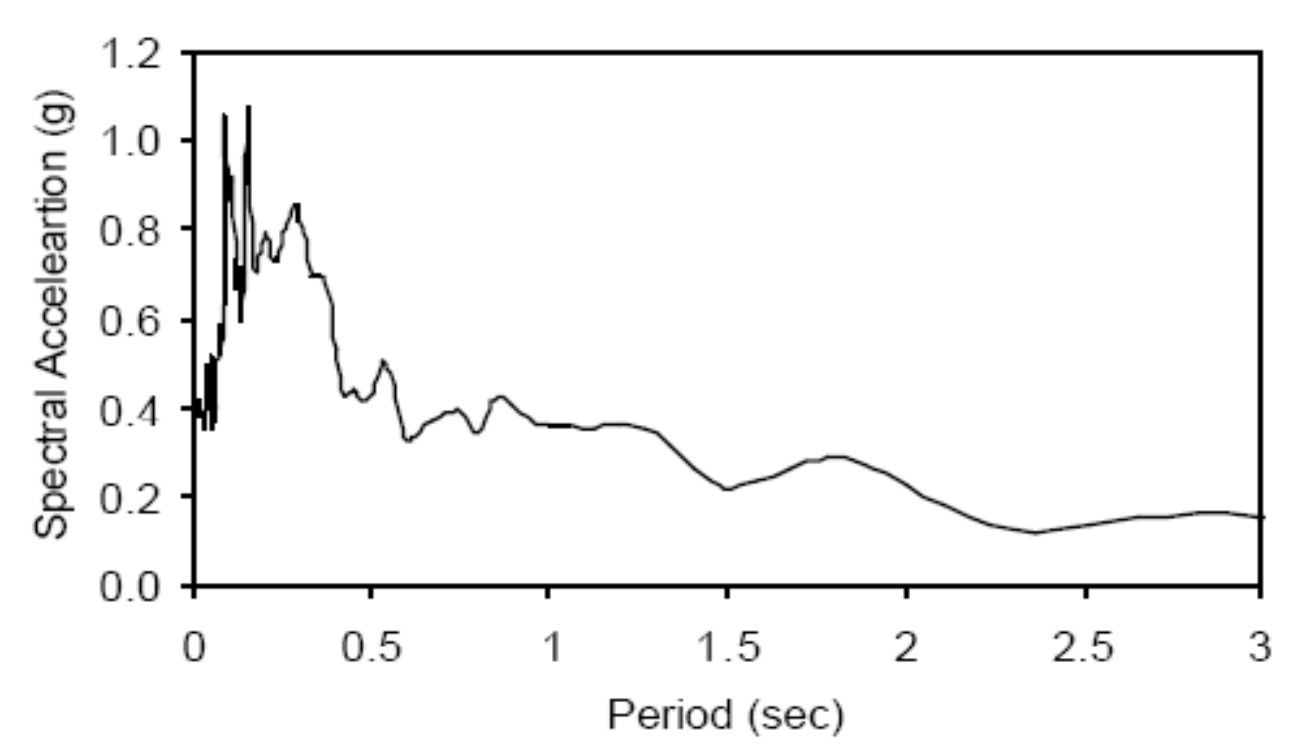

Figure (4) Response spectrum acceleration of Kocaeli earthquake [7]



Figure (5) X-component of base shear along the tank height for various full cases



Figure (6) X-component of moment along the tank height for various full cases 
University of Thi-Qar Journal Vol.10 No.2 June 2015

Web Site: https://jutq.utq.edu.iq/index.php/main Email: journal@jutq.utq.edu.iq

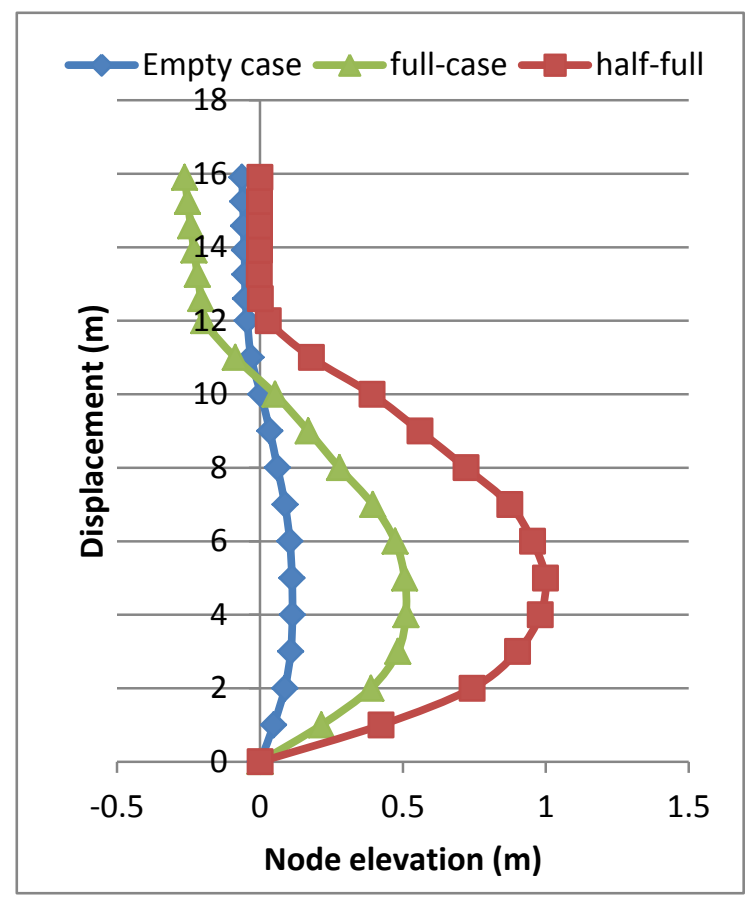

Figure (8) Maximum (displacement-

for three full cases

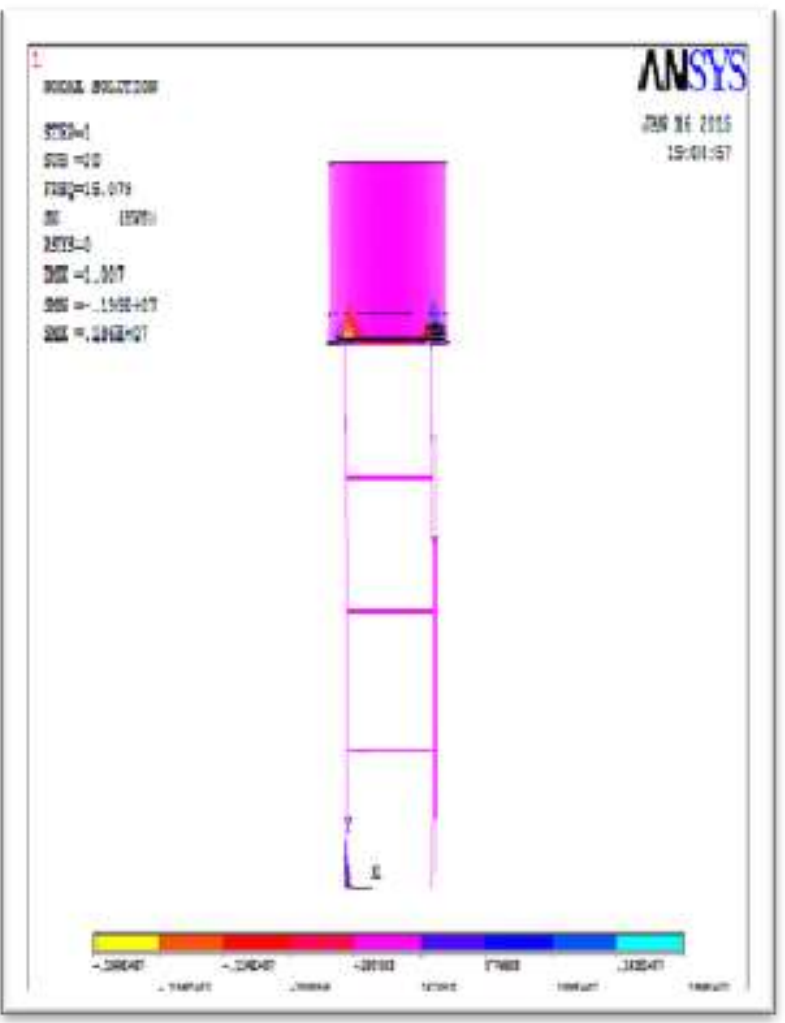

Figure (10) x-component of stress for the tank using ANSYS 11 software



Figure (7) Displacement in x-direction filling degree) variation

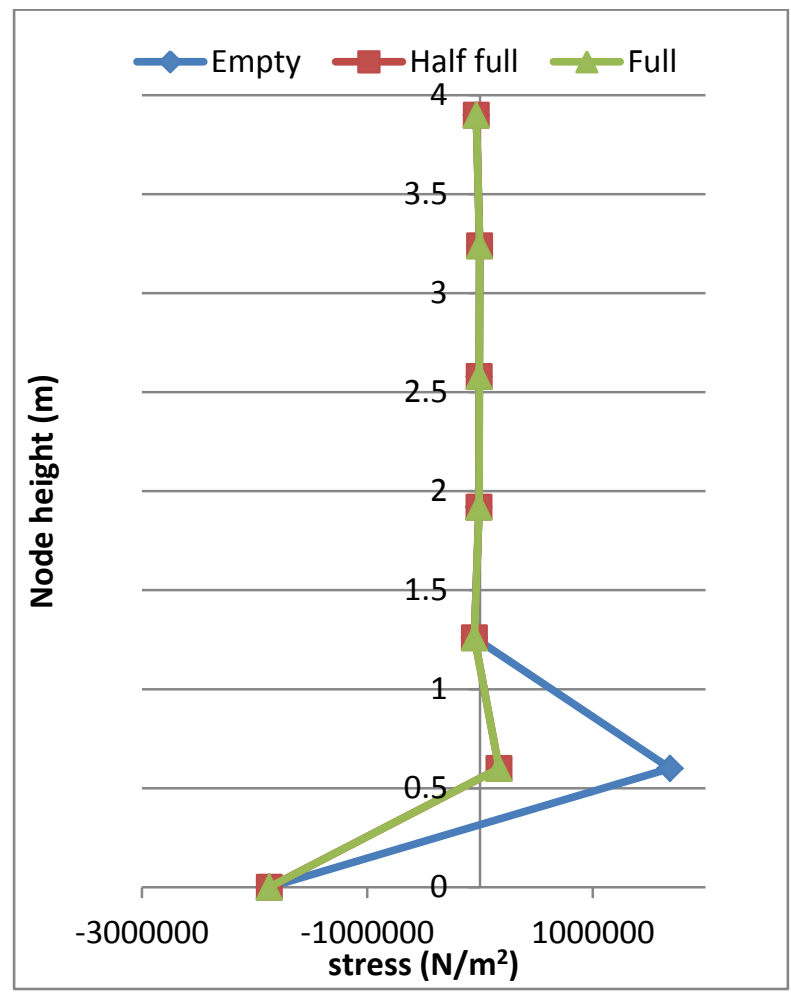

Figure (9) Stress distribution on the empty container body height 
Web Site: https://jutq.utq.edu.iq/index.php/main Email: journal@jutq.utq.edu.iq

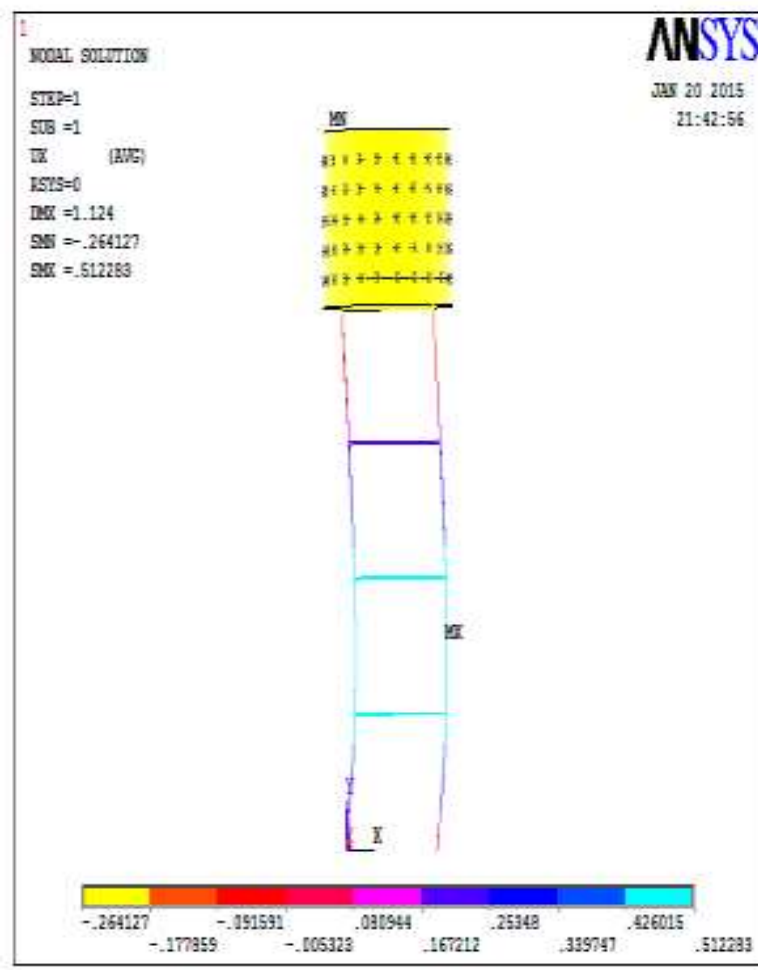

Figure (11) Contour plot of displacement in $\mathrm{x}$-direction for full case

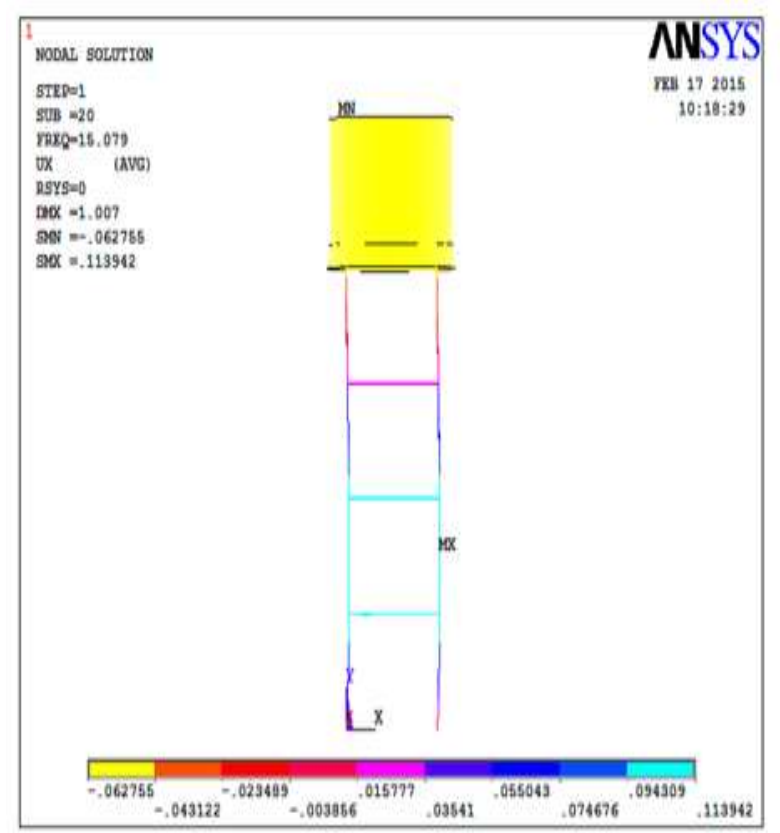

Figure (13) Contour plot of displacement in $\mathrm{x}$-direction for empty tank

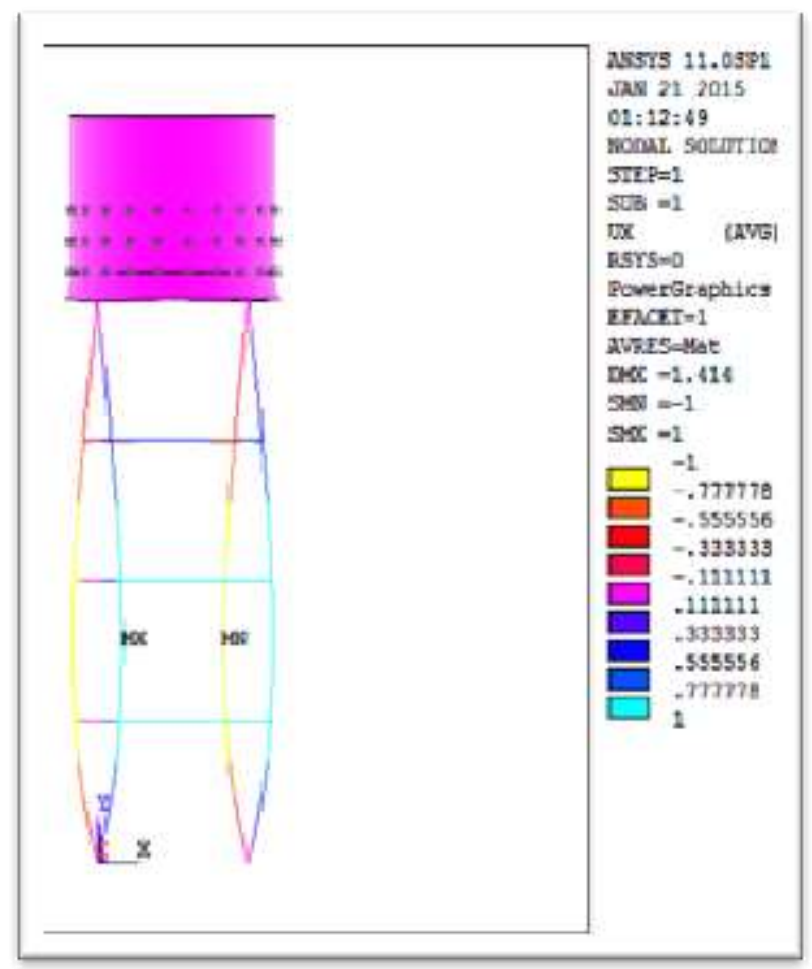

Figure (12) Contour plot of displacement in $\mathrm{x}$-direction for half full case

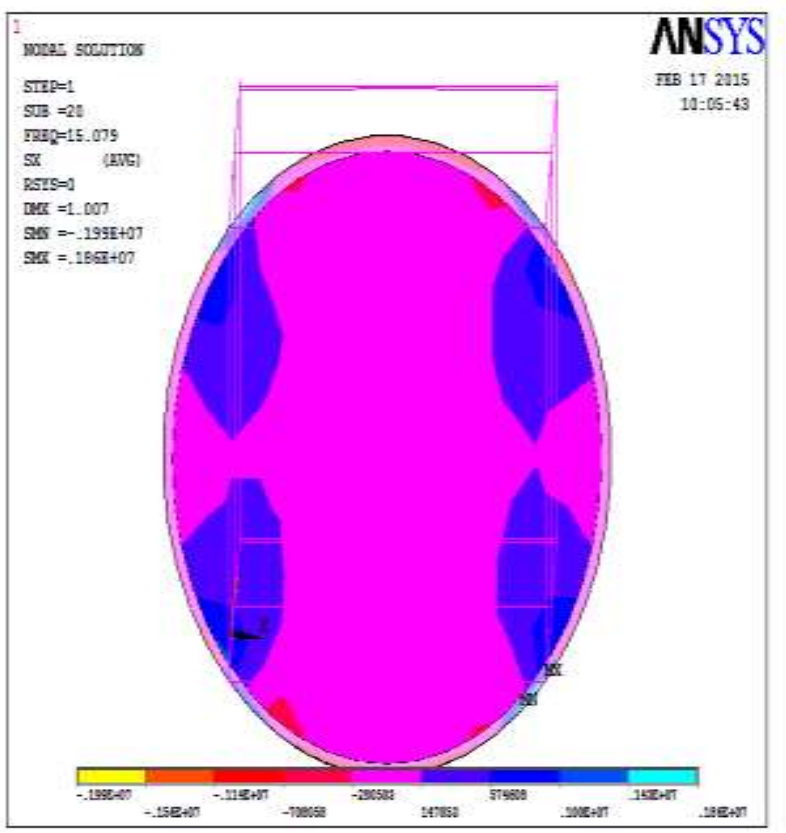

Figure (14) Stress distribution around the base plate of the container

\section{Conclusion}




\section{University of Thi-Qar Journal Vol.10 No.2 June 2015}

Web Site: https://jutq.utq.edu.iq/index.php/main Email: journal@jutq.utq.edu.iq

The main conclusions that can be obtained from the study are:

- The critical response of elevated tanks may occur in full or half full condition. This depends on the coincidence of the natural frequency and the earthquake characteristics in reduction or amplification of system responses.

- The maximum stress occurs in the points of connection between frame and container's body which subject to high loading due to the big mass of the container connected to the slender frame that these points suffer from.

- Natural frequency decreases as frame height increases, when frame height is doubled the natural frequency increment is found to be equal $(68 \%)$.

- Frame inclination increment lead to frequency decrement because: stiffness of columns and beams decrease and their masses increase that give reverse effect on the natural frequency values.

- The lateral displacement in the x-direction due to earthquake has it's maximum value near the middle of frame height because of the column-buckling.

\section{ACKNOWLEDGMENTS}

Praise and thanks to Allah who Reconciles me to complete this study. I would like to express my thanks and regard to my supervisor, Dr. Abdulamir A. Karim for his time and help during all stages of this work I also thank Dr. (Mohammed Jawad K. Essa), head of civil engineering department. Also thanks to Dr. (Rabee'a Hashim Thjeel), dean of college of engineering.

\section{References}

1. Ghandhi M.N. \& Rajan A. "Necessity of Dynamic Analysis of Elevated Water Storage Structure Using Different Bracing in Staging", international Journal of research in advent Technology, Vol.2, No.2, February, 2014.

2. Omidinasab F. \& Shakib H. "Seismic vulnerability of elevated water tanks using performance based- design", the $14^{\text {th }}$ world conference on earthquake engineering, October, 12-17, 2008, Beijing, China.

3. Soroushnia S., Tafreshi Sh. T., Omidinasab F., Beheshtian N. \& Sajad Soroushnia "Seismic Performance of RC Elevated water Tanks with frame staging and Exhibition Damage Pattern", The Twelfth East Asia Pacific conference on structural engineering and construction,2011.

4. Patel C. N., Kanjetawala B. \&Patel H.S. "Influence of frame type tapered staging on sloshing behavior of elevated water tank ", International Journal of advanced Engineering research and studies, Dec., 2012. 
University of Thi-Qar Journal Vol.10 No.2 June 2015

Web Site: https://jutq.utq.edu.iq/index.php/main Email: journal@jutq.utq.edu.iq

5. Hirde S., Bajar. A. \& Hedaoo M. "Seismic Performance of Elevated water tanks", International Journal of Advanced engineering research and studies, vol.I/Issue I/ OctoberDecember, 2011.

6. ANSYS 11.0 Inc.," Ansys user's manual", version11.0, USA, 2013.

7. Soyoz S. "Effect of soil structure Interaction and Base Isolated System on seismic performance of foundation soils", Master Thesis, July, 2004. 